\title{
Early Infantile Epileptic Encephalopathy 32
}

National Cancer Institute

\section{Source}

National Cancer Institute. Early Infantile Epileptic Encephalopathy 32. NCI Thesaurus.

Code C155998.

An autosomal dominant form of early infantile epileptic encephalopathy, caused by mutation(s) in the KCNA2 gene, encoding potassium voltage-gated channel subfamily A member 2. 